\title{
Fabrika Çalışanlarının İş Memnuniyetini Etkileyen Etmenler
}

MEHMET KÖK*

mkok@atauni.edu.tr
ARZU CAKICI ${ }^{* *}$

arzucakici@mynet.com

Özet: Bu çalı̧manın amacı Kocaeli-İzmit merkez atık geri dönüşüm fabrikalarında çalı̧anların iş doyumunun Minesota Doyum Ölçeği ile ölçülerek yaş, cinsiyet, medeni durum, eğitim düzeyi, toplam gelir, kıdem, çalı̧sma saati, yöneticilik, işs seçimi, işe uygunluk, işe bağllik, gece nöbeti, yöneticilik ve kişisel ihtiyaçların karşılanmasını içeren demografik değişkenlerle ne kadar yordandiğını incelemektir. Çalışmaya, İzmit ilinde 2013 yılında kolay ulaşılabilir örnekleme yöntemiyle seçilmiş 150 iş̧̧i katılmıştır, ancak veri toplama araçları 67 kişiden geri alınabilmiştir. Katılımcılara, Demokratik Bilgi Toplama Formu ve Minnesota İş Doyum Ölçeği uygulanmış, verilerin analizi için frekans dağılımı ve tek yönlü varyans analizi kullanılmıştır.

Yapılan analizler sonucunda, örnekleme girenlerin yaş, cinsiyet, medeni durum, eğitim düzeyi, toplam gelir, kıdem, çalışma saati ve yöneticilik boyutlarına ve bu boyutların genel ortalamasina göre anlaml fark bulunamamış $(P>0,05)$ ancak statü, iş seçimi, iş uygunluğu, işe bağlllık, gece nöbeti, kişisel ihtiyaçların karşılanması boyutlarının genel ortalamasina göre anlaml fark bulunmuştur $(P<0,05)$. Buna göre iş doyumu; işini koşullar gereği değil de kendi isteğ i ile seçenlerde, işinin kendisine uygun olduğunu, işine bağh olduğunu düşünen ve gece nöbeti olmayan personelde daha yüksek bulunmuştur. Ayrıca yemek ve giyim gibi kişisel ihtiyaçları işyeri tarafından karşılanan personelin iş doyumu, karşılanmayanlara göre yüksektir. Statü değişkeninde ise, idari işlerde çalı̧an personelin $(X=3,14)$ iş doyumları, idare ve teknik elemandan $(X=3,99)$ daha düşük bulunmuştur. Yine yapılan Dunnett's $C$ testine göre işçiler $(X=3,39)$ ile idari elemanların $(X=3,14)$ iş doyumu, idari ve teknik personelden $(X=3,99)$ daha düşük bulunmuştur.

Anahtar kelimeler: İ̧̧ doyumu, İş̧iler, Fabrikalar.

\section{Giriş}

Mesleki etkinlikler insan yaşamının yaklaşık $1 / 3$ ünü kapsamaktadır. Sağlıklı insan, iş yaşamında çalışarak potansiyellerini kullanır, bundan da hoşlanır ve mutlu olur. Kişinin iş yaşamındaki mutluluğu, genel yaşamına yansımaktadır. İş doyumu, bu

\footnotetext{
* Doç. Dr., Atatürk Üniversitesi, K.K. Eğitim Fakültesi, Okul Öncesi Eğitimi Anabilim Dalı.

** Psikolojik Danışman, Kocaeli Yarbay Refik Cesur İlkokulu.
} 
nedenle endüstri psikologlarının ve iş danışmanlarının önemle üzerinde durduğu konulardan birisidir (Kuzgun, Aydeniz ve Hamamcı 1999, 14).

İş doyumu, birçok yazar ve araştırmacı tarafından değişik biçimlerde tanımlanmıştır. Bütün bu tanımlardan en önemli olan, literatürde en sık rastlanan ve iş doyumu konusunu araştıran kişiler tarafından en çok atıfta bulunulan tanımlar aşağıda belirtilmektedir.

İş doyumu insanları çalışmaya sevk eden önemli bir etken, gösterdikleri çabalar sonucunda elde ettikleri başarı umutlarıdır. Bu umutlar gerçekleştiğinde doyum söz konusu olmaktadır. Ortaya konan arzu ve ihtiyaçlar her şeyden önce insanın kendi benliği ile yakından ilişkili olmaktadır. Bu nedenle iş doyumu aynı zamanda bireyin kendi egosunun doyum yolu olarak tanımlanabilmektedir

Bir kısım görüşte iş doyumunun bir çalışanın işinden aldığı zevkin derecesiyle ilgili olduğu, bireylerin işlerinden hoşlanma derecesi olduğu, iş ortamında çalışanın isteklerinin bir şekilde karşılanması sonucu ortaya çıkan memnuniyeti ifade ettiği söylenmiştir (Başaran 2000, 28).

Bir başka görüşe göre iş doyumu, iş şartlarının (işin kendisi, fiziksel ortam, yönetimim tutumu) ya da işten elde edilen sonuçların (ücret, iş güvenliği) iş gören tarafından değerlendirilmesidir. İş doyumu işgörenin normlar, değerler ve beklentiler sisteminden geçerek değerlendirilen iş ve iş koşullarına ilişkin algılarına karşı geliştirdiği tepkilerden oluşmaktadır ( Gençtürk ve Memiş 2010, 1040).

Akın ve Koçak (2007), Davis (1988)'in, iş doyumunu işgörenlerin işlerinden duydukları hoşnutluk veya hoşnutsuzluk olarak tanımladığını belirtmişlerdir (Akın ve Koçak 2007, 355).

İş doyumu ya da doyumsuzluk durumunun, işgücü devrini, işe devamsızlı̆̆ yakınmayı ve diğer önemli personel konuları yakından etkilediği belirtilmektedir. Temel olarak kişinin beklentileri ve mevcut gerçeklik arasındaki farka bağlıdır. İş doyumu ya da doyumsuzluk durumunun, işgücü devrini, işe devamsızlığı, işten yakınmayı ve diğer önemli personel konuları yakından etkilediği belirtilmektedir. Temel olarak kişinin beklentileri ve mevcut gerçeklik arasındaki farka bağlıdır. Bu nedenle kişinin işinden bekledikleri ve işin ona verdiklerini bulmak önemlidir (Çinar ve Kavlak 2009, 34).

İş doyumu, iş görenlerin işlerinden duydukları hoşnutluk ya da hoşnutsuzluktur. İş doyumu işin özellikleri ve bireylerin istekleri birbirine uyduğu zaman gerçekleşmektedir (Sat 2011, 4).

İş doyumu ile ilgili tanımlar incelendiğinde, aralarında büyük ölçüde benzerlik olduğu görülmektedir (Taşdan ve Tiryaki 2008, 57).

Çalışanın işinden elde ettiği doyumu, işten ne elde etmek istediği, ne kadar elde etmek istediği ve ne elde etiğine olan inançların bileşkesi sonucunda oluşan duygusal durumdur (Işıkhan 1996, 119). 
Diğer bir grup araştırmacı ise iş doyumunu bir semptom olarak değerlendirmektedir; yetersiz iş tasarımı hem iş doyumsuzluğunun hem de olumsuz iş davranışlarının ortaya çıkmasına neden olmaktadır (Ergin 1997, 26-27). İşyerindeki fiziksel (gürültü düzeyi, havalandırma miktarı, ışıklandırma durumu, kalabalıklık v.b.) bireysel (sorumluluk miktarı, iş yükü, rollerdeki belirginlik düzeyi v.b), kişilerarası (amirler ve meslektaşlarla ilişkiler) ve kurumsal faktörler (belirsizlik, idari politikalar, çok fazla ya da az yapılandınlmışlık), çalışanların iş doyumundaki artışlar ya da azalmalarla ilişkili olduğu belirtilmektedir (Batıün vd 2006, 33).

İş doyumu ya da doyumsuzluğu, çalışanların işlerine, iş yerlerine ya da iş arkadaşlarına yönelik duygu düşünce ve davranışlarının bir bütünü olması bakımından içsel değerlendirmeleri ile yaptıkları işe yönelik genel bir tutumu belirtmektedir (Solmuş 2004,186).

“İş doyumu ilk kez 1920’ lerde ortaya atılmış, asıl önemi 1930’ lu ve 1940’lı yıllarda anlaşılmıştır. O yıllardan bu yana ilgili alandaki literatürün en fazla çalışılan konusu haline geldiği görülmektedir. (Yıldırım, 254).

Diğer taraftan, Pelit ve Öztürk (2010), endüstri ve örgütsel psikoloji alanında, iş doyumuyla ilgili çalışmaların büyük yer tutacak miktarda olduğunu belirten Locke (1976)' un konuyla ilgili yayınlanan makale sayısının 3.350'nin üzerinde olduğunu belirttiğini vurgulamışlardır. (Pelit ve Öztürk 2010, 44).

$\mathrm{Bu}$ açıklamalar doğrultusunda ve yapılan literatür taramalarında ülkemizde sanayi sektöründe çalışanların iş doyumlarının bireysel demografik değişkenlerle olan ilişkileri konusunda yapılmış çalışma sayısının oldukça sınırlı olduğu görülerek söz konusu araştırmanın yapılması planlanmıştır.

\section{Kavramlar}

\section{İş Doyumsuzluğu}

İş doyumu, işe yönelmeyi sağlayan olumlu bir etkendir. İş doyumu yüksek olan kişiler ile iş doyumu düşük olan kişiler arasında davranış farklılıkları olduğu saptanmıştır. İş doyumu yüksek olan kişilerin işe güdülenmesi ve verdikleri hizmetin kalitesi yükselmektedir.

İş doyumunun düşük olması ile personel değişim hızı, performansın düşmesi, işe devamsızlık, doyumsuzluğu pekiştirici iş ortamı, çalışma ekibi ile ilgili zorluklar, kurumsal engeller gibi faktörler arasında yakın bir ilişki bulunmaktadır (Akt: Çam, O. ve ark; 2005, 214).

Beehr ve Newman 1978, Dua 1996, iş doyumundaki azalmaların, kişinin hayatındaki olumsuz yaşam olaylarıyla, gündelik sıkıntılarla ve kişilik özellikleriyle de birleşince, genellikle, huzursuzluk, gerginlik, öfke, anksiyete, depresyon, yorgunluk gibi subjektif duygulanımlar ve soğuk algınlıklarında artış, allerjik reaksiyonlar, gastroentestinal hastalıklar ve madde kullanımı gibi fizyolojik sorunlarla ilişkili gördüklerini belirtilmiştir (Batıgün ve Şahin 2006, 33). 
Eren 2001'e göre iş ile ilgili sorunlar ve bunun sonucunda ortaya çıkan olumsuz tutumlar; işin yapılış koşullarına ve iş aletlerine bağlı yakınma ve doyumsuzluklar, bir işte çalışma sonucunda elde edilecek maddi çıkarlarla ilgili yakınma ve doyumsuzluklar, takdir edilme ve sosyal saygınlık durumlarıyla ilgili yakınma ve doyumsuzluklardır (Dede ve Çınar 2008, 4).

Kişilerin isleri ile ilgili beklentilerinin gerçekleşmemesi, hayal kırıklıkları yasaması memnuniyetsizlik ile sonuçlanır. İş memnuniyetsizliğini etkileyen birçok etmen bulunmaktadır. Literatürde kişilik yapısı, yas, cinsiyet, toplumsal cinsiyet rolü, isin özelikleri gibi birçok etmen ile is memnuniyetsizliği arasında ilişki olduğu bildirilmiştir. Yapılan çalışmalar is memnuniyeti ile isin olumlu havası, kişinin özgürlügüunde artış olduğu duygusu, basarı duygusu ve is üzerinde kontrolü olduğu duygusu arasında ilişki bulunduğu gösterilmiştir (Yasan vd. 2008, 229).

İş doyumsuzluğunun, genel yaşam doyumu, fiziksel sağlık ve ruhsal sağlık üzerine olumsuz etkilerinin yanı sıra, işe devamsızlık, işten ayrılma, iş v eriminin düşmesi gibi örgütsel etkileri de olabilmektedir.

Çalışanların iş doyumu, meslek grupları arasında değişiklik gösterebileceği gibi, aynı meslek grubunda, ülkeler, bölgeler ve kurumlar arasında da farklılıklar olabilmektedir (Durmuş ve Günay 2007, 140).

\section{İş Doyumunun Özellikleri}

İş doyumunun dört önemli özelliği bulunmaktadır:

1. İş doyumu, iş ile ilgili farklı tutumları temsil etmektedir. Diğer bir deyişle, iş görenler işin belirli boyutlarına karşı olumlu tutumlara sahipken, diğerlerine karşı olumsuz tutumlara sahip olabilirler. Bu nedenle genel iş doyumu bulunurken, iş doyumunun farklı boyutları incelenmelidir (Sat, 2011).

2. İş doyumu derecesi, genellikle çıktıların, beklentileri ne ölçüde karşıladığına bağlı olmaktadır (Sat, 2011).

3. İş doyumu, iş ortamında oluşan duruma karşı verilen duygusal yanıt olmaktadır.

$\mathrm{Bu}$ nedenle görülememekte, sadece hissedilmekte ya da ifade edilmektedir.

4. İş doyumu dinamik bir kavramdır. Bir kez iş doyumunun sağlanması sürekli aynı seviyede tutulabileceği anlamına gelmemektedir. İş doyumu hızla elde edilebildiği gibi hızla da iş doyumsuzluğuna dönüşebilmektedir. İş yerindeki fiziksel, bireysel, kişiler arası ve kurumsal faktörler iş görenlerin iş doyumundaki yükselme veya düşmelerle yakından ilişkili olmaktadır (Sat, 2011).

\section{İş Doyumunu Etkileyen Faktörler}

İş tatmini ile işten ayrılma eğilimi ve iş verimliliği arasında bir bağın bulunduğu bilinmektedir. Bu nedenle, Tütüncü ve Çiçek (2000)' e göre birçok araştırmac1, iş tatminini ölçümleyerek, iş ortamında daha olumlu bir iklim yaratılmasına yardımcı 
olacak faktörleri belirlemeye çalışmaktadır (Toker 2007, 93). İş doyumuna ilişkin literatür tarandığında araştırmacıların, iş doyumuna ilişkin farklı teori ve modelleri açıladıkları görülmesine rağmen üzerinde birleştikleri nokta, söz konusu bu olgunun, içsel ve dişsal faktör bileşenlerinden oluşmasıdır (Pelit ve Öztürk 2010, 47). İş doyumuna etki eden faktörler kapsamında da değerlendirilebilecek içsel faktörler, bireyin işinden doyum sağlamasında etken olan ve bireyi içten güdüleyici olan başarı, tanınma, ilginç veya rekabet gerektiren görev, sorumluluk, yükselme ve gelişme olanağ 1 verme gibi faktörleri kapsamaktadır. Diğer taraftan, Judge ve arkadaşları (2001), dışsal faktörlerin, bireyin işinden doyum sağlamasına katkıda bulunan ve bireyin örgüt içinde sağlıklı çalışması için örgüt tarafından gerçekleştirilmesi beklenen-gereken örgüt prosedürleri, denetim, kişiler arası ilişkiler, çalışma koşulları vb. gibi faktörleri kapsadığını düşünmektedir (Pelit ve Öztürk 2010, 47).

\section{Bireysel Faktörler}

Bireysel faktörler, değerler, beklentiler, cinsiyet, kişilik, eğitim, zeka, statü, tecrübe, sosyo-kültürel çevre olarak sıralanabilmektedir.

\section{a. Beklentiler}

Beklenmedik başarı ve başarısızlık üzerine yaptıkları araştırmada deneklerin çoğunun beklenen başarısızlığı, beklenmeyen başarıya tercih ettiklerini saptamışlardır (Sat 2011, 7).

\section{b. Cinsiyet}

Ülkemizde yapılan bazı çalışmalara bakıldığında da birbiriyle tutarlı sonuçlara ulaşılamamış olduğu görülmektedir. Çarıkçı (2004) tarafından yapılan bir araştırmada kadın çalışanların iş doyumunun, erkek çalışanların iş doyumundan düşük olduğu belirlenmiştir. Çarıkçı, kadın çalışanlarda doyumsuzluk yaratan faktörün çalışma saatlerindeki düzensizlik olduğunu belirtmiştir. Şahin (2003) 'ün yaptığ araştırmada iş doyumunun cinsiyete göre farklılık göstermediğini tespit etmiştir (Sat 2011, 7).

\section{c. Yaş}

Genel olarak, iş doyumu yaşla birlikte artmaktadır. Gençlerde daha düşük iş doyumu görülmektedir. Çünkü genç insanların çoğu sorumluluk duydukları ve kendilerini yeterli hissettikleri bir iş bulmakta başarılı olmadıkları için ilk işlerinde hayal kırıklığına uğramaktadır. Herzberg ve arkadaşlarına göre ise, yaş ve tatmin arasında U seklinde bir ilişki mevcuttur. Böyle bir ilişkiye göre çalışanların 25 yaş öncesi ile 45 yaş sonrasında iş tatmin düzeyleri yükselmektedir. Yani iş tatmini, işe ilk girişte yüksek, fakat sonra düşmektedir. İşteki kariyer yükseldikçe tatmin düzeyi de yeniden artmaya başlamaktadır (Sat 2011, 8).

\section{d. Unvan}

Amerikan Ulusal Görüş Araştırma Merkezinin 1972 ve 1978 yılları arasında uyguladığı anketlerden toplanan veriler baz alınarak yapılan bir araştırmada araştırmacılar, 
bireyin hiyerarşik konumunun iş doyumu üzerindeki etkisini araştırmışlar ve yalnızca 1974 yılının verilerini kullanarak elde ettikleri sonuç, prestij, yaş ve gelir düzeyi kontrol edildiğinde, bu etkinin iş doyum düzeyi ölçümünde $\% 4,8^{\prime}$ lik bir varyansı karşılayabildiği görülmüştür. Diğer yılların verileri ile yapılan istatistiksel çalışmalarda bu oranın sadece \%2 olması, unvanın iş doyumuyla ilgili bir değişken olarak kabul edilebilmesinin kuraldan çok bir istisna olduğunu vurgulamalarına yol açmıştır (Ebeling ve King 1981, 568).

\section{e. Kişilik}

Birçok bilimsel araştırma, çalışma yaşamı ile kişilik arasında bir etkileşimin olduğunu göstermektedir. Yine araştırmalara göre işlerine daha iyi uyum sağlayan ve duygusal dengesi daha iyi olan çalışanların iş doyumları daha yüksek olmaktadır. Bazı araştırmacılara göre, genelde iş doyumsuzluğu yaşayan çalışanlar çevreye uyum sağlayamayan, insan ilişkileri zayıf, fazla sinirli olan, kişisel konumlarından hoşnut olmayan bireyler olmaktadır (Sat, 2011).

\section{f. Ĕgitim}

Eğitim, iş doyumunu etkileyen en önemli faktörlerden birisi olmaktadır. Burada önemli olan, eğitim doğrultusunda ortaya çıkan bilgi birikimi, çalışma değerleri, özlem düzeyleri, örgütsel beklentiler gibi faktörlerle, yapılan işin sağladığı ortam ve olanaklar arasında dengenin sağlanması olmaktadır (Sat, 2011).

\section{g. Öğrenim durumu}

Öğrenim düzeyi ve iş doyumu arasındaki ilişkiyi, alınan eğitim ve işin gerektirdiği bilgi ve beceriler arasındaki uyum üzerinden inceleyen bir araştırmada, öğrenim düzeyi bireyin işinin gerektirdiğinden çok yüksekse bu durum iş doyumsuzluğunu yaratmakta; öğrenim düzeyinin işin gerektirdiğinden orta derecede yüksek olması halinde bu iki değişken arasındaki etkileşimin çok az olduğu görülmüştür. Türkiye’de yapılan bir araştırmanın sonucu ise öğrenim düzeyinin Türk çalışanlarının iş doyumuna önemli bir etkisinin olmadığını göstermektedir (Bilgiç 1998, 549-558). Ancak, öğrenim düzeyi görece yüksek olan çalışanlar verimlilik ile daha yakından ilgilidirler ve işlerine karşı daha az olumsuz duygu geliştirmişlerdir; başka bir deyişle bu çalışanlar işle ilgili unsurlar konusunda fazla şikayetçi olmazken, iş performanslarının kalitesi ile daha çok ilgilidirler (Yelboğa 2007, 5).

\section{h. Zeka}

Zeka, yapılan işle ilgili olarak ele alındığında iş doyumunda önemli bir etken olmaktadır. Birçok iş ve meslekler belirli bir zeka seviyesi gerektirmekte ve bunun altında ya da üzerinde zekaya sahip kişiler bu işlerden doyum elde edememektedir (Sat 2011, 10).

\section{Statü}

Mesleki statü yükseldikçe iş doyumu da artmaktadır. Üst düzeyde olanların alt dü- 
zeyde olanlara göre iş doyum düzeyi daha yüksek olmaktadır. Bunun nedeninin, üst düzeydeki çalışanların daha yüksek ücretli, kişisel beklentilere daha fazla cevap veren işlerde çalışmaları olduğu görülmektedir (Sat 2011, 10).

\section{i. Tecrübe ya da Kıdem}

Yapılan birçok araştırmada, mesleki çalışma süresi arttıkça işten duyulan tatmininde arttığı görülmektedir. Bu durum, işten beklentilerin daha gerçekçi temellere oturmaya başlaması, kişinin kendisini iş ortamına uydurması, yüksek pozisyonlarda ücret ve çalışma şartlarının iyi olmasından kaynaklanmaktadır (Sat 2011, 10). Bu bağlamda çalışma yaşamına yeni başlayan, iş tecrübesi az olan bireylerin beklentileri çoğunlukla gerçekçi olmamakta ve karşılanmayan beklentileri iş doyumsuzluğuna yol açmaktadir.

\section{Çevresel ya da Örgütsel Faktörler}

Örgütsel faktörler, bireysel faktörlerle etkileşime geçerek çalışanların iş doyumlarını etkilemektedir. İş doyumunu etkileyen örgütsel faktörler ise; yönetim biçimi, çalışma olanakları, gelişme ve yükselme olanakları, ücret, stres, işin niteliği, çalışma arkadaşları, güvenlik ve fiziksel ortam, takdir edilme ve terfi olarak belirlenebilmektedir.

\section{a. Yönetim Biçimi}

Liderlik ve yönetim tarzı çalışanların motivasyonu ve iş tatmini üzerinde iki boyutta etkilidir. Bunlardan birincisi çalışan merkezli olmaktır. Yöneticilerin personel ilişkilerini desteklemesi ve katkıda bulunması çalışanların iş doyumlarını artırmaktadır. İkinci boyut ise karar verme sürecine çalışanların katılımıdır. Bu katılım iş doyumunu önemli oranda artırmaktadır. Robbins,1996’ ya göre, örgüt ortamı içerisinde çalışanlar, yaptıkları işin başkaları tarafından takdir edildiğini gördüklerinde, işlerinde daha fazla doyumu sağlarlar. Örgütte genel olarak karmaşıklık ve biçimsel ilişkiler, iş doyumunun düşmesine yol açar (Taşdan ve Tiryaki 2008, 59).

\section{b. Çalışma Olanakları ve Koşulları}

Yapılan işin gerçekleştirilebilmesi ve çalışabilme için gerekli araç-gereç, kütüphane, bilgisayar gibi olanaklarla, kantin, yemekhane, spor ve dinlenme ile ulaşım gibi fizyolojik gereksinimleri karşılayacak olanakların yeterliliğidir (Yerlisu ve Çelenk 2008, 89).

Çalışma koşulları: Başaran (2000)'e göre, çalışma ortamının uygun olmaması, rahatsız edici olması, araç-gereç sıkıntısı, işyerine ulaşımın zor olması vb. çalışanda doyumsuzluk yaratacak değişkenlerden sayılabilir (Taşdan ve Tiryaki 2008, 59).

\section{c. Gelişme ve Yükselme Olanakları}

İş doyumu açısından yükselme ve gelişme olanaklarının, ücretten daha etkili olduğu yapılan çalışmalar sonucunda saptanmıştır. İş yerinde terfi olanaklarının ve verilen ödüllerin iş doyumu üzerinde etkileri olduğu görülmüştür. Terfilerin adil olması ve bir temele dayanması çalışanlar açısından önemlidir (Yerlisu ve Çelenk 2008, 89). 


\section{d. $\ddot{U}$ cret}

Çalışanların iş tatminini etkileyen en önemli unsurlardan biri de ücrettir. İş doyumu konusunda ücretin önemi işten işe değişebilmektedir (Akt: Sat, 2011). Bir işgören örgüte verdiği emeğinin de karşılığını, ödeme olarak geri almalıdır. Ödeme, işgörenin örgütten sağladığı her türlü parasal, toplumsal ve ruhsal karşılıkları kapsar (Taşdan ve Tiryaki 2008, 59).

\section{e. Stres}

Stres, her kişi üzerinde aynı etkiyi göstermeyen ve bireyin endişe, üzüntü, gerilim ve baskıya yol açan duyguları yaşaması olarak tanımlanmaktadır. Stres, çalışan kişilerde iş doyumsuzluğu yaratmaktadır.

\section{f. İşin Niteliği}

İşin niteliği yükseldikçe, genel olarak işten duyulan doyumu artmaktadır (Kağan, 2005). Çalışanlar, kendilerinin beceri ve yeteneklerini kullanma fırsatı veren işleri tercih etme eğilimdedirler. Tekdüze yapılmayan işlerde, genellikle iş tatmin düzeyi artmaktadır. Çalışanların aşırı baskı altında çalışmayı sevmemelerinin yanısıra her konuda işlerine karışılmasından ve kendilerine emir verilmesinden de hoşlanmadıkları görülmektedir.

\section{g. Çalışma Arkadaşları}

Çalışanın, çalışma arkadaşlarına ve çalıştığı gruba kendisini ait hissetmesi iş doyum düzeyini etkilemektedir. Çalışma arkadaşları, kişinin iş doyumunu kişi işinde ya da örgütte yeni olduğunda güçlü bir şekilde etkilemektedir. Çünkü çalş̧an işe yeni başladığında işle ilgili neleri yapması ve neleri yapmaması gerektiğini bilmemektedir.

Çalışma arkadaşları bu nedenle çalışanların iş doyumunu etkilemektedir (Akt: Sat, 2011). Çalışanın başarılı sayılan bir grup içerisinde yer alması, hayat görüşü kendisine uygun insanlarla birlikte çalışması iş doyumunu artırmaktadır. Bu nedenle çalıştığı işletmede dostlar ve destekleyici iş arkadaşları bulan çalışanın iş doyumu artmaktadır. İşyerinde, işverenin tutumu da iș doyumunu çok etkilemektedir. İșverenin arkadaş̧̧a ve anlayışı davrandığında da iş doyumunun arttığı dikkati çekmektedir (Yerlisu ve Çelenk 2008, 88).

\section{h. Güvenlik ve Fiziksel Ortam}

İş güvenliğinin olması, çalışan için ayrı bir iş doyum faktörü olmaktadır. Çalışanlar işinde güvenlik unsurunun tam olarak var olduğuna ve kendisine değer verildiğine inanıyorsa, bu durum çalışanın işinden doyum elde etmesine yardımcı olacaktır (Yerlisu ve Çelenk 2008, 88).

\section{Takdir Edilme}

Erdil ve arkadaşlarına (2004) göre, çalışanların performansının gereğine uygun olarak takdir edilmesi, değerlendirilmesi ve ödüllendirilmesi, çalışanların yaptığı işler- 
den daima gurur duyması, sahip olduğu kariyerde ilerleme fırsatlarından tatmin olması iş tatminini olumlu yönde etkilemektedir (Bozkurt ve Bozkurt 2008, 5).

Mesleğinde maddi ve manevi doyuma ulaşamayan çalışan, işine yoğunlaşamamakta ve verimli çalışamamaktadır. Barutçugil (2004)'e çalışanların yeterli düzeyde motive edil(e)mediği ve iş doyumu sağlan(a)madığında çoğu kez yeteneklerini kullanmadıkları ve potansiyellerini performansa dönüştür(e)medikleri gözlenmektedir (Yılmaz ve Ceylan 2011, 280).

Çalışanların iş yaşamlarındaki doyumlarını ve doyumsuzluklarını ortaya koymak amacıyla birçok literatür çalışması yapılmış ve bu çalışma sonuçlarından hareketle ilgili kuram ve yaklaşımlar üretilmiştir. Yapılan bu çalışmalarda da görüldüğü gibi iş doyumu kavramı, çoğunlukla işe yönelik tutumların anlamıyla eş değer olarak düşünülmektedir. Bu çalışmada da açıklandığı üzere, işle ilgili tutumlar, içsel faktörler (kişisel özellikler) tarafından ya da dışsal faktörler (kişiyi etkileyen çevresel güçler) tarafından belirlenebilmektedir. Yani iş doyumu birbirinden farklı birçok faktör ile etkileşim içinde olmaktadır.

Yukarıdaki açıklamalar ve yapılan literatür taramaları doğrultusunda ülkemizde sanayi sektöründe çalışanların iş doyumlarının bireysel demografik değişkenlerle olan ilişkileri konusunda yapılmış çalışmaların yeterince kapsamlı olmadığı görülerek alana bir nebze de olsa katkı sağlaması amacıyla bu araştırmanın yapılması planlanmiştır.

\section{Amaç}

Yukarıda ifade edilen temel sorun bağlamında bu araştırmanın genel amacı; sanayi sektöründe bireysel demografik değişkenlerin, iş doyumu üzerindeki etkisini belirlemektir.

Araştırmada bu genel amaca ulaşabilmek için, aşağıdaki sorulara cevap aranmıştır;

1. "Yaş" değişkeni, personelin iş doyumunun anlamlı bir yordayıcısı mıdır?

2. "Cinsiyet" değişkeni, personelin iş doyumunun anlamlı bir yordayıcısı mıdır?

3. "Eğitim durumu” değişkeni, personelin iş doyumunun anlamlı bir yordayıcısı mıdir?

4. "Medeni durum" değişkeni, personelin iş doyumunun anlamlı bir yordayıcısı mıdir?

5. "Toplam gelir” değişkeni, personelin iş doyumunun anlamlı bir yordayıcısı mıdır?

6. "İş deneyimi (Kıdem)" değişkeni, personelin iş doyumunun anlamlı bir yordayıcisi midir?

7. "Statü” değişkeni, personelin iş doyumunun anlamlı bir yordayıcısı mıdır?

8. "Mesai saati” değişkeni, personelin iş doyumunun anlamlı bir yordayıcısı mıdır?

9. "İş seçimi” değişkeni, personelin iş doyumunun anlamlı bir yordayıcısı mıdır?

10. "İş uygunluğu" değişkeni, personelin iş doyumunun anlamlı bir yordayıcısı mıdir?

11. "İşe bağlılık" değişkeni, personelin iş doyumunun anlamlı bir yordayıcısı mıdır?

12. "Gece nöbeti" değişkeni, personelin iş doyumunun anlamlı bir yordayıcısı mıdır? 
13. "Yöneticilik" değişkeni, personelin iş doyumunun anlamlı bir yordayıcısı mıdır?

14. "Kişisel ihtiyaçların karşılanması" değişkeni, personelin iş doyumunun anlamlı bir yordayıcısı midır?

\section{Yöntem}

İş doyumunun bireysel demografik değişkenler ile ilişkisini inceleyen tarama türündeki bu araştırmanın yöntem bölümünde araştırma grubu, veriler ve toplanması, veri toplama aracı ve verilerin analizine verilmiştir.

\section{Araştırma Grubu}

$\mathrm{Bu}$ çalışmanın örneklemini, KOCAELİ-İZMİT merkezde faaliyet gösteren geri dönüşüm fabrikalarında görev yapan 150 çalışan oluşturmuştur. Veriler, 150 personele dağıtılmış ancak 67 kişiden geri alınabilmiştir. Katılımcıların 18’si kadın, 49'u erkektir. Örneklemin yaş aralığı 18-56'dir. Katılımcılar gönüllü olarak çalışmaya katılmıştir.

\section{Veriler ve Toplanmasi}

Verilerin toplanması ilgili fabrika kuruluşlarında araştırmacı tarafından gerçekleştirilmiştir. Araştırma için kullanılan ölçme aracı araştırma grubuna dağıtılmış ve doldurulduktan sonra toplanmıştır.

\section{Veri Toplama Araci}

$\mathrm{Bu}$ çalışmada veriler, uygulanan iki farklı veri toplama aracı yoluyla toplanmıştır. Bağımlı değişkene (iş doyumu) ilişkin verilerin toplanmasında, "Minnesota

Doyum Ölçeği”; bireylerin kişisel bilgilerini toplamak için ise " Sosyodemografik Bilgi Formu” kullanılmıştır.

\section{Sosyodemografik Bilgi Toplama Formu}

Anket Formu; 14 sorudan oluşmaktadır. Fabrika çalışanlarının tanımlayıcı özellikleri, çalışma koşulları, meslekleri ile ilgili düşünce ve memnuniyetleri, mesleklerini seçme nedenlerini içeren sorulardan oluşmaktadır.

\section{Minnesota İş Doyum Ölçeği}

Araştırmada kullanılan ölçek, Weiss, David, England ve Lofquist (1967) tarafından iş doyumunu ölçmek amaciyla geliştirilen ve 20 sorudan oluşan Minnesota İş Doyum Ölçeğidir. Baycan (1985) tarafından Türkçeye çevrilip, geçerlilik ve güvenilirlik çalışmaları yapılmıştır (Cronbach Alpha = 0,77). Minnesota İş Doyum Ölçeği 1-5 arasında puanlanan beşli likert tipi bir ölçektir. Ölçek puanlamasında, Hiç memnun değilim; 1 puan, Memnun değilim; 2 puan, Kararsızım; 3 puan, Memnunum; 4 puan, Çok memnunum; 5 puan olarak değerlendirilmektedir. Ölçekte ters soru bulunmamaktadır. Minnesota İş Doyum Ölçeği içsel, dışsal ve genel doyum düzeyini belirleyici özelliklere sahip 20 maddeden oluşmuştur. 1- İçsel doyum 1, 2, 3, 4, 7, 8, 9, 10, 11 , 
15, 16, 20 2- Dişsal doyum 5, 6, 12, 13, 14, 17, 18, 19 3-Genel doyum: 1, 2, 3,4, 5, 6, 7, $8,9,10,11,12,13,14,15,16,17,18,19,20$ maddelerini içermektedir. Genel doyum puanı 20 maddeden elde edilen puanların toplamının 20'ye, içsel doyum puanı 1, 2, $3,4,7,8,9,10,11,15,16,20$ içsel faktörleri oluşturan maddelerden elde edilen puanların toplamının 12'ye, dişsal doyum puanı 5, 6, 12, 13, 14, 17, 18, 19 dışsal faktörleri oluşturan maddelerden elde edilen puanların toplamının 8'e bölünmesi ile elde edilmektedir. Ölçeğin nötr doyum puanı 3'tür. Ölçekten alınan puan 3'ten küçük ise iş doyumu düşük, 3 'ten büyük ise iş doyumu yüksek olarak değerlendirilmektedir (Çam vd. 2005, 213-220).

\section{Verilerin Analizi ve Yorumlanması}

Minnesota İş Doyum Ölçeği ile toplanan veriler, analiz için SPSS 13.0 for Windows programına girilmiştir. Veri girişi tamamlandıktan sonra araştırmanın amaçları doğrultusunda uygun istatistik teknikler kullanılarak analiz edilmiştir.

İki grup ortalamaları iki ortalama arasındaki farkın önemlilik testi, t testi; üç ve ya daha fazla grup ortalamaları ANOVA analizi ile karşılaştırılmıştır. Tüm veriler için istatistiksel anlamlılık düzeyi $\mathrm{P}<0,05$ olarak alınmıştır. Analizlerde cinsiyet, yaş, iş deneyimi (kıdem) ,medeni hal, eğitim düzeyi, toplam gelir, statü, mesai saati, iş seçimi, iş uygunluğu, işe bağlılık, gece nöbeti, yöneticilik görevi, kişisel ihtiyaçların karşılanıp karşılanmadığı değişkenleri kullanılmıştır.

$\mathrm{Bu}$ doğrultuda, araştırmada yer alan değişkenler arasındaki ilişkilerin değerlendirilmesi amacıyla ölçeğe verilen yanıtların personelin cinsiyet,medeni durum,iş seçimi,işe uygunluk,işe bağlılık,gece nöbeti,yöneticilik ve kişisel ihtiyaçların karş1lanması göre değişip değişmediğine t-testi ile; yaş,eğitim düzeyi,toplam gelir,statü, mesai saati ve iş deneyimi (kıdem) durumuna göre değişip değişmediğine ise Tek Yönlü Varyans Analizi (ANOVA) ile bakılmış, gruplar arasında fark bulunduğunda farklılıkların hangi gruplar arasında olduğunu belirlemek üzere post-hoc Scheffe ile Dunnett's C testleri yapılmıştır.

\section{Bulgular}

Tablo 1: Çalışmaya katılanların demografik özellikleri

\begin{tabular}{|lcc|}
\hline Demografik özellikler & N: 67 & $\%$ / SD \\
\hline Yaş Aralı̆̆ı & & \\
$18-29$ & 39 & 58,2 \\
$30-41$ & 20 & 29,9 \\
42 ve üzeri & 7 & 10,4 \\
\hline Cinsiyet & & \\
Kadın & 18 & 26,9 \\
Erkek & 49 & 73,1 \\
\hline
\end{tabular}




\begin{tabular}{|c|c|c|}
\hline \multicolumn{3}{|l|}{ Ĕ̈itim Durumu } \\
\hline İlkokul mezunu & 14 & 20,9 \\
\hline Ortaokul mezunu & 19 & 28,4 \\
\hline Lise mezunu & 15 & 22,4 \\
\hline Ön lisans - lisans - yüksek Lisans & 19 & 28,4 \\
\hline \multicolumn{3}{|l|}{ Medeni hal } \\
\hline Evli & 30 & 44,8 \\
\hline Bekar & 37 & 55,2 \\
\hline \multicolumn{3}{|l|}{ Toplam gelir } \\
\hline Düşük & 9 & 13,4 \\
\hline Orta & 40 & 59,7 \\
\hline Yüksek & 18 & 26,9 \\
\hline \multicolumn{3}{|l|}{ Çalışma yılı } \\
\hline $1-7$ yil & 42 & 62,7 \\
\hline 8-14 yll & 14 & 20,9 \\
\hline 15 ve üzeri & 11 & 16,4 \\
\hline \multicolumn{3}{|l|}{ Statü } \\
\hline Yönetim ve teknik eleman & 10 & 14,9 \\
\hline İşçiler & 38 & 56,7 \\
\hline İdari işler ve hizmet & 19 & 28,4 \\
\hline \multicolumn{3}{|l|}{ Çalışma saati } \\
\hline $1-5$ saat aras 1 & 8 & 11,9 \\
\hline 6-10 saat arası & 54 & 80,6 \\
\hline $11-15$ saat arası & 5 & 7,5 \\
\hline \multicolumn{3}{|l|}{ İs seçimi } \\
\hline Kendi isteği ile & 51 & 76,1 \\
\hline Koşullar gereği & 16 & 23,9 \\
\hline \multicolumn{3}{|l|}{ İş uygunluğu } \\
\hline Uygun & 30 & 44,8 \\
\hline Uygun değil & 37 & 55,2 \\
\hline \multicolumn{3}{|l|}{ İşe bağllık } \\
\hline Bağlıyım & 43 & 64,2 \\
\hline Bağglllı̆gım yok & 24 & 35,8 \\
\hline \multicolumn{3}{|l|}{ Gece nöbeti } \\
\hline Var & 24 & 35,8 \\
\hline Yok & 43 & 64,2 \\
\hline \multicolumn{3}{|l|}{ Yöneticilik görevi } \\
\hline Var & 9 & 13,4 \\
\hline Yok & 58 & 86,6 \\
\hline
\end{tabular}




\begin{tabular}{|lcc|}
\hline Kişisel ihtiyaçları sağlama & & \\
Evet & 46 & 68,7 \\
Hayır & 21 & 31,3 \\
\hline İş memnuniyeti düzeyi & & \\
Düşük & 14 & 20,9 \\
Nötr & 5 & 7,5 \\
Yüksek & 48 & 71,6 \\
\hline
\end{tabular}

Tablo 2: Fabrika Çalışanlarının Cinsiyete Göre İş Doyumu Puan Ortalamalarının TTesti Sonuçları

\begin{tabular}{lcccccc}
\hline Cinsiyet & $\mathrm{N}$ & $\mathrm{X}$ & $\mathrm{S}$ & $\mathrm{sd}$ & $\mathrm{t}$ & $\mathrm{P}$ \\
\hline Kadin & 18 & 3,600 &, 554 & 65 & 1,337 &, 186 \\
Erkek & 49 & 3,336 &, 763 & & & \\
\hline
\end{tabular}

Fabrika çalışanlarının iş doyumu puan ortalamaları cinsiyete göre anlamlı bir farklılık göstermemektedir. Başka bir deyişle, kadın personelin iş doyum düzeyleri ile erkek çalışanların iş doyum düzeyleri arasında herhangi bir fark yoktur ( $t(65)=$ $1,337, \mathrm{P}>, 05)$.

Tablo 3: Fabrika Çalışanlarının Medeni Hale Göre İs Doyumu Puan Ortalamalarının T- Testi Sonuçları

\begin{tabular}{lcccccc}
\hline Medeni hal & $\mathrm{N}$ & $\mathrm{X}$ & $\mathrm{S}$ & $\mathrm{sd}$ & $\mathrm{t}$ & $\mathrm{P}$ \\
\hline Evli & 30 & 3,51 &, 77 & & & \\
Bekar & 37 & 3,32 &, 67 & 65 & 1,087 &, 281 \\
\hline
\end{tabular}

Fabrika çalışanlarının iş doyum düzeylerinin medeni duruma göre anlamlı bir farklılık göstermemektedir ( $t(65)=1,087, \mathrm{P}>$,05). Başka bir deyişle, evli personelin iş doyum düzeyleri ile bekar çalışanların iş doyum düzeyleri arasında herhangi bir fark yoktur.

Tablo 4: Fabrika Çalışanlarının İş Seçimi Durumuna Göre İş Doyumu Puan Ortalamalarının T- Testi Sonuçları

\begin{tabular}{lcccccc}
\hline$\dot{I S s ̧ s ~ s e c ̧ i m i ~ d u r u m u ~}$ & $\mathrm{~N}$ & $\mathrm{X}$ & $\mathrm{S}$ & $\mathrm{sd}$ & $\mathrm{t}$ & $\begin{array}{c}\mathrm{P} \\
\text { Anlamlıfark }\end{array}$ \\
\hline Kendi isteği ile & 51 & 3,51 &, 662 & 65 & 2,180 &, 033 \\
Şartlara bağlı & 16 & 3,07 &, 811 & & & \\
\hline
\end{tabular}

Personelin toplam iş doyumu puanları, iş seçimine göre anlamlı bir farklılık göstermektedir $(\mathrm{t}(65)=2,180, \mathrm{P}<, 05)$. Bu bulguya göre kendi isteği ile işlerini seçen personelde iş doyumu daha yüksek olacaktır. 
Tablo 5: Fabrika Çalışanlarının Işe Uygunluk Durumuna Göre İş Doyumu Puan Ortalamalarının T- Testi Sonuçları

\begin{tabular}{lcccccc}
\hline İşuygunluğu & $\mathrm{N}$ & $\mathrm{X}$ & $\mathrm{S}$ & $\mathrm{sd}$ & $\mathrm{t}$ & $\begin{array}{c}\mathrm{P} \\
\text { Anlamlı fark }\end{array}$ \\
\hline Uygun değil & 30 & 3,09 &, 827 & 45,568 & 3,273 &, 002 \\
Uygun & 37 & 3,65 &, 500 & & & \\
\hline
\end{tabular}

Yukarıdaki tabloda da görüldüğü gibi fabrika personelinin iş doyumu puanları, işe uygunluk durumuna göre anlamlı bir farklılık göstermektedir $(\mathrm{t}(45,568)=3,273, \mathrm{P}$ $<, 05$ ). Bu bulguya göre işlerinin kendilerine uygun olduğunu düşünen personelde iş doyumu daha yüksek olacaktır.

Tablo 6: Fabrika Çalışanlarının İşe Bağhlık Durumuna Göre İş Doyum Puan Ortalamalarının T- Testi Sonuçları

\begin{tabular}{lcccccc}
\hline İşe bağlılık & $\mathrm{N}$ & $\mathrm{X}$ & $\mathrm{S}$ & $\mathrm{sd}$ & $\mathrm{t}$ & $\begin{array}{c}\mathrm{P} \\
\text { Anlamlı fark }\end{array}$ \\
\hline İşe bağlıyım & 43 & 3,67 &, 605 & 65 & 4,665 &, 000 \\
İşe bağlı değilim & 24 & 2,93 &, 664 & & & \\
\hline
\end{tabular}

Tabloda da görüldüğü gibi fabrika personelinin iş doyumu puanları, işe bağlılık durumuna göre anlamlı bir farklılık göstermektedir ( $\mathrm{t}(65)=4,665, \mathrm{P}<, 05)$. Bu bulguya göre işlerine bağlı olduğunu düşünen personelde iş doyumu daha yüksek bulunmuştur.

Tablo 7: Fabrika Çalışanlarının Gece Nöbeti Durumuna Göre İş Doyum Puan Ortalamalarının T-Testi Sonuçları

\begin{tabular}{lcccccc}
\hline Gece nöbeti & $\mathrm{N}$ & $\mathrm{X}$ & $\mathrm{S}$ & $\mathrm{sd}$ & $\mathrm{t}$ & $\begin{array}{c}\mathrm{P} \\
\text { Anlaml fark }\end{array}$ \\
\hline Var & 24 & 2,98 &, 853 & 32,093 & 3,471 &, 002 \\
Yok & 43 & 3,64 &, 502 & & & \\
\hline
\end{tabular}

Tabloda da görüldüğü gibi fabrika personelinin iş doyumu puanları, gece nöbetinin olup olmaması durumuna göre anlamlı bir farklılık göstermektedir $(\mathrm{t}(32,093)=$ $3,471, \mathrm{P}<, 05)$. Bu bulguya göre çalıştığ fabrikada gece nöbeti olmayan personelin iş doyumu daha yüksek bulunmuştur.

Tablo 8: Fabrika Çalışanlarının Kişisel İhtiyaçlarının Karşılanması Durumuna Göre İs Doyum Puan Ortalamalarının T- Testi Sonuçları

\begin{tabular}{lcccccc}
\hline $\begin{array}{l}\text { Kişisel ihtiyaçların } \\
\text { karşılanması }\end{array}$ & $\mathrm{N}$ & $\mathrm{X}$ & $\mathrm{S}$ & $\mathrm{sd}$ & $\mathrm{t}$ & $\begin{array}{c}\mathrm{P} \\
\text { Anlamlıfark }\end{array}$ \\
\hline Evet & 46 & 3,55 &, 615 & 65 & 2,412 &, 019 \\
Hayır & 21 & 3,10 &, 845 & & & \\
\hline
\end{tabular}


Yukarıdaki tabloda da görüldüğü gibi fabrika personelinin iş doyumu puanları, yeme-içme,giyim vb. gibi bir kısım ihtiyaçların karşılanması durumuna göre anlamlı bir farklılık göstermektedir ( $\mathrm{t}(65)=2,412, \mathrm{P}<, 05)$. Bu bulguya göre çalıştığı fabrikada bir kısım kişisel ihtiyaçları karşılanan personelin iş doyumu daha yüksek bulunmuştur.

Tablo 9: Fabrika Çalışanlarının Yönetici Olup Olmama Durumlarına Göre İş Doyum Puan Ortalamalarının T- Testi Sonuçları

\begin{tabular}{lcccccc}
\hline Yöneticilik & $\mathrm{N}$ & $\mathrm{X}$ & $\mathrm{S}$ & $\mathrm{sd}$ & $\mathrm{t}$ & $\mathrm{P}$ \\
\hline Var & 9 & 3,52 &, 611 & 65 &, 512 &, 610 \\
Yok & 58 & 3,39 &, 737 & & & \\
\hline
\end{tabular}

Tabloda da görüldüğü gibi fabrika personelinin iş doyumu puanları, çalıştığı işyerinde yöneticiliklerinin olup olmaması durumuna göre anlamlı bir farklılık göstermemektedir ( $\mathrm{t}(65)=, 512, \mathrm{P}>$,05). Başka bir değişle işyerinde yöneticilik görevi olan personel ile diğer personelin iş doyumları aynıdır.

Tablo 10a: Uyum Ölçeği Puanlarının Betimsel İstatistikleri

\begin{tabular}{lccl}
\hline Yaş & N & X & SS \\
\hline $18-29$ & 39 & 3,33 &, 642 \\
$30-41$ & 20 & 3,53 &, 899 \\
42 ve üzeri & 7 & 3,40 &, 638 \\
\hline
\end{tabular}

Tablo 10b: Fabrika Çalışanlarının Yaş Aralıklarına Göre İş Doyum Ölçeği Puanlarının ANOVA Sonuçları

\begin{tabular}{lccccc}
\hline Varyansın kaynă̆ $ı$ & Kareler toplamı & sd & Kareler ortalaması & F & P \\
\hline Gruplararası &, 564 & 2 &, 282 & \multirow{2}{*}{, 530} & \multirow{2}{*}{591} \\
Gruplariçi & 33,505 & 63 &, 532 & & \\
Toplam & 34,069 & 65 & & & \\
\hline
\end{tabular}

Analiz sonuçları, personelin genel iş doyumu düzeyleri arasında yaş düzeyleri bakımından anlamlı bir fark olmadığını göstermektedir, $\mathrm{F}(2,63)=, 530, \mathrm{P}>, 05$.

Tablo 11a: Uyum Ölçeği Puanlarının Betimsel İstatistikleri

\begin{tabular}{lccc}
\hline Ĕ̆itim Düzeyi & $\mathrm{N}$ & $\mathrm{X}$ & SS \\
\hline İlkokul & 14 & 3,50 &, 761 \\
Ortaokul & 19 & 3,22 &, 816 \\
Lise & 15 & 3,51 &, 805 \\
Ön Lisans - Lisans - Yüksek Lisans & 19 & 3,45 &, 500 \\
\hline
\end{tabular}


Tablo 11b: Fabrika Çalışanlarının Eğitim Düzeyine Göre Iş Doyum Ölçeği Puanlarının ANOVA Sonuçları

\begin{tabular}{lccccc}
\hline Varyansın kaynağı & Kareler toplamı & sd & Kareler ortalaması & F & P \\
\hline Gruplararası & 1,016 & 3 &, 339 &, 645 & \multirow{2}{*}{, 589} \\
Gruplariçi & 33,090 & 63 &, 525 & & \\
Toplam & 34,106 & 66 & & & \\
\hline
\end{tabular}

Analiz sonuçları, personelin genel iş doyumu düzeyleri arasında eğitim düzeyleri bakımından anlamlı bir fark olmadığını göstermektedir, $\mathrm{F}(3,63)=, 645, \mathrm{P}>, 05$.

Tablo 12a: Uyum Ölçeği Puanlarının Betimsel İstatistikleri

\begin{tabular}{lccc}
\hline Toplam gelir & N & X & SS \\
\hline Düşük & 9 & 3,40 &, 781 \\
Orta & 40 & 3,37 &, 648 \\
Yüksek & 18 & 3,50 &, 862 \\
\hline
\end{tabular}

Tablo 12b: Fabrika Çalışanlarının Toplam Gelire Göre İş Doyum Ölçeği Puanlarının ANOVA Sonuçları

\begin{tabular}{lccccc}
\hline Varyansın kaynă̆ı & Kareler toplamı & sd & Kareler ortalaması & F & P \\
\hline Gruplararası &, 219 & 2 &, 109 & \multirow{2}{*}{206} & \multirow{2}{*}{814} \\
Gruplariçi & 33,89 & 64 &, 529 & & \\
Toplam & 34,11 & 66 & & & \\
\hline
\end{tabular}

Analiz sonuçları, personelin genel iş doyumu düzeyleri arasında toplam gelir bakımından anlamlı bir fark olmadığını göstermektedir, F $(2,64)=, 206, \mathrm{P}>, 05$.

Tablo 13a: Uyum Ölçeği Puanlarının Betimsel İstatistikleri

\begin{tabular}{llcc}
\hline Kıdem & $\mathrm{N}$ & $\mathrm{X}$ & SS \\
\hline $1-7$ yıl aras1 & 42 & 3,36 &, 652 \\
8-14yıl aras1 & 14 & 3,51 &, 791 \\
15 ve üzeri & 11 & 3,45 &, 911 \\
\hline
\end{tabular}

Tablo 13b: Fabrika Çalışanlarının Kıdeme Göre İş Doyum Ölçeği Puanlarının ANOVA Sonuçları

\begin{tabular}{lccccc}
\hline Varyansın kaynağ 1 & Kareler toplamı & sd & Kareler ortalaması & $\mathrm{F}$ & $\mathrm{P}$ \\
\hline Gruplararası &, 263 & 2 &, 131 & \multirow{2}{*}{, 248} & \multirow{2}{*}{, 781} \\
Gruplariçi & 33,843 & 64 &, 529 & & \\
Toplam & 34,106 & 66 & & & \\
\hline
\end{tabular}

Analiz sonuçları, personelin genel iş doyumu düzeyleri arasında kıdem bakımından anlamlı bir fark olmadığını göstermektedir, $\mathrm{F}(2,64)=, 248, \mathrm{P}>, 05$. 
Tablo 14a: Uyum Ölçeği Puanlarının Betimsel İstatistikleri

\begin{tabular}{llcl}
\hline Statü & $\mathrm{N}$ & $\mathrm{X}$ & SS \\
\hline Yönetim ve teknik eleman & 10 & 3,99 &, 233 \\
İşçiler & 38 & 3,39 &, 735 \\
İdari işler ve hizmet & 19 & 3,14 &, 702 \\
\hline
\end{tabular}

Tablo 14b: Fabrika Çalışanlarının İşyerindeki Statüye Göre İş Doyum Ölçeği Puanlarının ANOVA Sonuçları

\begin{tabular}{lccccc}
\hline Varyansın kaynă̆ı & $\begin{array}{c}\text { Kareler } \\
\text { toplamı }\end{array}$ & sd & $\begin{array}{c}\text { Kareler } \\
\text { ortalaması }\end{array}$ & F & $\begin{array}{c}\text { P } \\
\text { Anlamlı fark }\end{array}$ \\
\hline Gruplararası & 4,797 & 2 & 2,399 & 5,238 &, 008 \\
Gruplariçi & 29,309 & 64 &, 458 & & \\
Toplam & 34,106 & 66 & & & \\
\hline
\end{tabular}

Analiz sonuçları, personelin genel iş doyumu düzeyleri arasında işyerindeki statü bakımından anlamlı bir fark olmadığını göstermektedir, $\mathrm{F}(2,64)=5,238, \mathrm{P}>, 05$. Ancak, birimler arası farkların hangi gruplar arasında olduğunu bulmak amacıyla yapılan Post Hoc testlerden Scheffe testinin sonuçlarına göre; idari işlerde çalışan personelin $(X=3,14)$ iş doyumları, idare ve teknik elemandan $(X=3,99)$ daha düşük bulunmuştur. Yine yapılan Dunnett's $C$ testine göre işçiler $(X=3,39)$ ile idari elemanların $\mathrm{X}=3,14)$ iş doyumu, idari ve teknik personelden $(\mathrm{X}=3,99)$ daha düşük bulunmuştur.

Tablo 15a: Uyum Ölçeği Puanlarının Betimsel İstatistikleri

\begin{tabular}{lccl}
\hline Mesai Saati & N & X & SS \\
\hline $1-5$ saat & 8 & 3,30 &, 894 \\
$6-10$ saat & 54 & 3,42 &, 725 \\
$11-15$ saat & 5 & 3,50 &, 353 \\
\hline
\end{tabular}

Tablo 15b: Fabrika Çalışanlarının Mesai Saati Aralı̆̆ına Göre İş Doyum Ölçeği Puanlarının ANOVA Sonuçları

\begin{tabular}{lccccc}
\hline Varyansın kaynă̆ı & Kareler toplamı & sd & Kareler ortalaması & F & P \\
\hline Gruplararası &, 138 & 2 &, 069 & \multirow{2}{*}{, 130} & \multirow{2}{*}{878} \\
Gruplariçi & 33,968 & 64 &, 531 & & \\
Toplam & 34,106 & 66 & & & \\
\hline
\end{tabular}

Analiz sonuçları, personelin genel iş doyumu düzeyleri arasında mesai saatleri bakımından anlamlı bir fark olmadığını göstermektedir, $\mathrm{F}(2,64)=, 130, \mathrm{P}>, 05$. 


\section{Tartışma}

Analizlerde cinsiyet, yaş, iş deneyimi (kıdem) ve öğrenim düzeyi, medeni hal, toplam gelir, statü, mesai saati, iş seçimi, iş uygunluğu, işe bağlllık, gece nöbeti, yöneticilik görevi, kişisel ihtiyaçların karşılanıp karşılanmadığı gibi değişkenler araştırılmıştır.

Cinsiyet değişkeni erkek ve kadın olmak üzere iki grup altında incelenmiştir. Yaş değişkeni ile ilgili olarak; "18- 29", "30- 41" ve "42 ve üstü” olmak üzere üç grup olarak belirlenmiştir. Eğitim durumu, ilkokul, ortaokul, lise ile ön lisans ile lisans ve yüksek lisans kategorilerinde ele alınmıştır. Statü olarak idare ve teknik eleman, işçiler ve idari elemanlar olarak üç bölümde incelenmiştir. Çalışma saati olarak 1- 5, 6- 10 ve 11-15 olmak üzere üç kategoride ele alınmıştır. İş Deneyimi (kıdem) değişkeni ile ilgili olarak; "1- 5 yll", "6- 10 yll", "11-15 yll” olmak üzere üç grupta incelenmiştir. İş seçimi değiş̧keni, kendi isteğimle ve koşullar gereği olarak iki bölümde ele alınmıştır. İşe uygunluk değişkeni uygun değil ve uygun olarak ele alınmıştır. İşe bağlllık değişkeni bağlıyım ve bağlı değilim kategorilerini oluşturmuştur. Diğer değişkenler olan gece nöbeti değişkeni evet, hayır; yöneticilik görevinin olup olmadığı var, yok ve kişisel ihtiyaçların karşılanıp karşılanmadığı değişkeni ise yine evet ve hayır şeklinde incelenmiştir.

Yapılan analizler sonucunda, örnekleme giren yaş, cinsiyet, medeni durum, eğitim düzeyi, toplam gelir, kıdem, çalışma saati ve yöneticilik boyutlarına ve bu boyutların genel ortalamasına göre anlamlı fark bulunamamış $(P>0,05)$,statü, iş seçimi, iş uygunluğu, işe bağllık, gece nöbeti, yöneticilik, kişisel ihtiyaçların karşılanması boyutlarının genel ortalamasına göre anlamlı fark bulunmuştur $(P<0,05)$. Buna göre iş doyumu: işini koşullar gereği değil de kendi isteği ile seçenlerde, işinin kendisine uygun olduğunu, işine bağlı olduğunu düşünen ve gece nöbeti olmayan personelde daha yüksek bulunmuştur. Ayrıca yemek ve giyim gibi kişisel ihtiyaçları işyeri tarafından karşılanan personelin iş doyumu, karşılanmayanlara göre yüksektir.

Araştırmamızda iş doyumu açısından cinsiyet bir önemlilik arz etmemektedir. Kadın ve erkek çalışanlarda iş doyumunun farklı olmamasını kimi araştırmaların da desteklediği görülmektedir. Yurt dişında yapılan araştırmalarda evli olmak ve destekleyici bir eşe sahip olmak tükenmişliği önlemede önemli bir etken olarak bildirilmişse de, ülkemizde hekimlerde yapılan iki araştırmada araştırmamıza paralel olarak evli, bekar ya da dul/boşanmış olmanın tükenmişlik ve iş doyumu üzerine etkisinin olmadığı saptanmıştır (Erol vd. 2007, 245). Araştırmamızda medeni durum, iş doyumunu etkilememiştir. Mevcut çalışmada evli olmanın iş doyumunu olumlu yön de etkilediği görülmüsstür. Bu sonuç ülkemizde yapılan bir çalışma sonucu ile paralellik göstermektedir; ancak diğer çalışmalarda medeni durumun iş doyumunu etkilemediği bulunmuştur (Kavlu ve Pınar 2009, 1552).

Evli olmak ve yaşlı olmak iş ve yaşam doyumunu arttırıcı etkenler gibi görünmektedir. Çalışmamızda olduğu gibi Linn ve arkadaşları da (1985) evli ve daha yaşlı hekimlerde iş ve yaşam doyumunu daha yüksek saptamışlardır (Ünal vd. 2001, 117). 
Araştırmamızda toplam gelirin iş doyumunu etkilemediği saptanmıştır. Oysaki literatür tarandığında toplam gelirin iş doyumunu etkilediğine dair araştırmalar mevcuttur. Bu durum işe bağlılık, işinden hoşnut olma ile açıklanabilir. Ancak yine de ücret yüksekliğinin iş doyumunu olumlu yönde etkilemesi kaçınılmaz bir gerçektir.

Ücretlerin yükselme olanağ1, yönetim tarzı, işin kişiye genel uyumu ve iş arkadaşlarıyla olan genel ilişkiler, iş doyumunu etkileyen önemli etkenlerdir (Kurçer 2005, $10)$.

Statü değişkeninde ise, idari işlerde çalışan personelin $(\mathrm{X}=3,14)$ iş doyumları, idare ve teknik elemandan $(X=3,99)$ daha düşük bulunmuştur. Yine yapılan Dunnett's $C$ testine göre işçiler $(X=3,39)$ ile idari elemanların $(X=3,14)$ iş doyumu, idari ve teknik personelden $(\mathrm{X}=3,99)$ daha düşük bulunmuştur. İşyerinde emir altında olmayan personelin iş doyumunun daha yüksek olmasını aşağıdaki ifadeler de desteklemektedir. Bireyler sürekli kontrol altında bulunmaktan hoşlanmazlar. Keser (2006)'ya göre bu tür otoriter yaklaşımlar, çalışanların motivasyonlarını ve verimliklerini olumsuz etkiler; yaratıcılık ve yenilikçilik gibi özelliklerini törpüleyerek sürekli hata yapmalarına da yol açabilir (Dede ve Çınar 2008, 10).

Araştırmamızda, işe uygunluk değişkeni, iş doyumunu yordamaktadır. Başka bir değişle yaptıkları işin kendilerine uygun olduğunu düşünen fabrika personelinin iş doyumu yüksek bulunmuştur. Telman 2005'e göre iş yaparken kişiye ne derece özgürlük tanınıyorsa, bu, o derecede doyum verir. Çalışan, çalışma saatlerine kendi karar verebiliyor, çalışma yöntemlerini kendi seçebiliyor, yapılacak işlerin sırası konusunda söz sahibi olabiliyorsa, işindeki özerkliği yüksek kabul edilir. Ayrıca iş doyumuna ilişkin bir takım değişkenlerin bireyin iş doyumuna yönelik algılarında etkili olduğu düşünülmektedir. Örneğin bir iş ne kadar beceri gerektiriyorsa, kişiye o derece doyum vereceği düşünülür. Sürekli aynı türde, özellikle de pek fazla uzmanlık gerektirmeyen, çok kolay öğrenilebilen becerilerin kullanıldığı işlerde çalışanlar genellikle daha doyumsuzdurlar. (Keser 2006, 105).

Çalışanlar, genellikle işi yerine getirme konusunda belirli bir oranda da olsa kendilerine özgürlük tanınmış olan işleri tercih etme eğilimindedirler. Çalışanların deneyimlerini ve yeteneklerini yeterince kullanamadıkları görev ya da pozisyonlar doyumsuzluğa neden olabilirken, çalışanın nitelikleri ya da yeterlilikleriyle birebir örtüşen iş ya da pozisyonların mutluluk ve doyum yaratacağı beklenebilir (Solmuş 2004, 189). Araştırmamızda kıdem iş doyum üzerinde önemli bir etken değildir. Ancak literatür incelendiğinde şu bulgulara rastlamak mümkündür: İş yaşamına yeni başlamış olan kişiler işlerinden doyum sağlama eğiliminde olmaktadırlar. Bu dönemdeki teşvikler, becerilerin ve yeteneklerin gelişimini de kapsamaktadır. İş yeni olduğu için kişiye ilginç ve çekici görünebilir. Erken oluşan bu doyum, çalışanın ilerlemesi ve gelişmesi sürmeyince azalmaktadır. İşindeki ilk birkaç yıldan sonra çalışanın cesareti kırılmakta ve kurum içindeki terfisi oldukça yavaş olmaktadır. Yapılan çalışmalarda çalışma hayatının ilk yıllarında iş doyumunun daha yüksek olduğu bulunmuştur. İşe yeni başlayan çalışanlar, çalışma arkadaşlarından ve kendilerinden daha kıdemli olan çalışanlardan sosyal destek elde edemezlerse daha yüksek düzey- 
lerde iş doyumu bildirmektedirler. Türkiye'de yapılan bir araştırmada kıdemin dışsal iş doyumu ile negatif ilişkili olduğu bulunmuştur (Yelboğa 2007, 5).

Bir diğer değişken olan işe bağlılık durumu da araştırmamızda iş doyumunu yordar nitelikte olup yapılan bir çalışma sonucunda da, bireyin iş ortamını değerli, yaptığ 1 işi anlamlı ve kendisini geliştirici bulması, iş doyumu açısından önemli kriterlerdir. Bu durum bireyin yaşamdan keyif almasını, yaşamında mutlu olmasını sağlamaktadır. Dolayısıyla işini anlamlı bulan bireylerin, işinden ve yaşamdan daha fazla doyum aldıklarını söylemek olasıdır. İş yaşamından beklentilerini karşılaması, iş doyumunu pozitif yönde etkileyen diğer bir unsurdur. Beklentilerin karşılanmaması durumunda yaşam doyumunun olumsuz etkilendiğini söylemek mümkündür.

Araştırmamızda bir diğer değişken olan kişisel ihtiyaçların karşılanmasının da iş doyumunun üzerinde önemli bir etkisi vardır. İşyerinde kişisel ihtiyaçları karşılanan personelin iş doyumu daha yüksek bulunmuştur. Yapılan diğer araştırmalardaki bulgular da bu bulgumuzu kanıtlar niteliktedir. Çalışma ortamında fizyolojik gereksinimler için ödemeler; güvenlik gereksinimine sosyal güvenlik; ait olma ve sevgi gereksinimi için iş arkadaşları ile uyumlu çalışma, saygınlık gereksinimine unvan sahibi olma ve kendini gerçekleştirme için örgütte ilerleme örnek verilebilir (Kelecioğlu vd. 2007, 117).

\section{Sonuç ve Öneriler}

Geri dönüşüm fabrika çalışanlarında iş doyumunun ve iş doyumuna etki eden faktörlerin incelenmesi amacıyla yapılan bu araştırmanın sonucunda; fabrika çalışanlarının iş doyumlarını iş seçimi, işe uygunluk, işe bağlılık gibi içsel faktörlerle; statü, gece nöbeti ve kişisel ihtiyaçların karşılanması gibi dışsal faktörlerin etkilediği saptanmıştır. Çalışma hayatında iç ve dış faktörler sürekli etkileşim halindedir ve iş doyumu bu faktörlerden oldukça etkilenmektedir. Musal ve arkadaşlarının(1995) da belirtiği üzere iş doyumunu yaş, cinsiyet, eğitim düzeyi gibi kişisel özelliklerin yanı sıra, yapılan işin içeriği, ücret politikası, çalışma koşulları gibi kurumsal ve çevresel etkenler etkilemektedir (Ünal vd. 2001, 114). Davis,1988 in de belirttiği gibi genellikle işgörenler kendi iş koşullarını toplum koşullarıyla karşılaştırırlar, eğer iş koşulları vasat ancak toplum koşulları kötü ise, bu durum doyumlarını yükseltme eğilimindedir; çünkü kendilerini oransal olarak iyi sayarlar (Kayıkçı 2005, 518).

Diğer yandan Quarstein ve arkadaşları, iş doyum ve doyumsuzluğunun durumsal oluşumlardan (molalar, kötü yemekler) ve durumsal özelliklerden (iş arkadaşları, çalışma şartları vb. ) etkilendiğini savunmaktadır. Buna göre, içsel ve dışsal faktörler önemli olsa dahi durumsal koşulların birbiri ile etkileşiminin önemlidir İş doyumunu etkileyen faktörlerin incelenmesi, iş doyumunu artırmaya yönelik önlemlerin alınması için oldukça önemlidir (Şahin ve Dursun 2009, 161).

Çalışılan ortamının olumsuz fiziksel koşulları, yetersiz araç ve gereçler, mesleki gelecek kaygıları, yoğun çalışma temposu gibi nedenler iş verimini, sağlığı ve sosyal yaşantıyı etkilemekte, bu etkilenmede iş doyumunda azalmaya neden olabilmektedir (Çan vd. 2006, 19). 
Çalışmanın sonucunda araştırmamızda fabrika çalışanlarının iş doyumunu olumsuz etkileyen etkenler ile yukarıda değinilen iş hayatı olumsuzluklarının ortadan kaldırılmasının iş doyumunu pozitif yönde etkileyeceği düşünülmektedir. İçsel ve dışsal faktörlerde iyileşme oldukça iş doyumunun da arttığ1 göz önünde bulundurularak bundan sonraki çalışmaların iş doyumunu arttırıcı girişimlere yönelik olarak planlanması önerilmektedir.

\section{Kaynakça}

Akın, Uğur ve Recep Koçak. Yaz 2007. "Öğretmenlerin Sınıf Yönetimi Becerileri ile İş Doyumları Arasındaki İlişkiler”. Kuram ve Uygulamada Eğitim Yönetimi 51: 353-370.

Başaran, İbrahim Ethem. 2000. Örgütsel Davranış: Insanın Üretim Gücü. Ankara: Feryal Matbaasi.

Batıgün, Durak, Ayşegül ve Nesrin Hisli Şahin. 2006. "İş Stresi ve Sağlık Psikolojisi Araştırmaları İçin İki Ölçek: A-Tipi Kişilik ve İş Doyumu”. Türk Psikiyatri Dergisi 17/1: 32-45.

Bilgiç, Ramazan. 1998. "The Relationship Between Job Satisfaction and Personal Characteristics of Turkish Workers”. Journal of Psychology 132/5: 549-558.

Bozkurt, Öznurve İlhan Bozkurt. 2008. "İş Tatminini Etkileyen İşletme İçi Faktörlerin Eğitim Açısından Değerlendirilmesine Yönelik Bir Alan Araştırması”. Doğuş Üniversitesi Dergisi 9/1: 1-18.

Çam, Olcay, Ebru Akgün, Aysun Gümüş Babacan, Ayşegül Bilge, Ünal Keskin. 2005. "Bir ruh sağlığı ve hastalıkları hastanesinde çalışan hekim ve hemşirelerin klinik ortamlarını değerlendirmeleri ile iş doyumları arasındaki ilişkinin incelenmesi." Anadolu Psikiyatri Dergisi 6/2: 213-220.

Çam, Olcay, Ebru Akgün, Aysun Gümüş Babacan, Ayşegül Bilge, Emine Çan, Murat Topbaş, Asuman Yavuzyılmaz, Gamze Çan ve Şükrü Özgün. 2006. "Hekimlerin Tükenmişlik Sendromu ile İş Doyumu Düzeyleri ve İlişkili Faktörler”. O.M. U. Tip Dergisi 23/1: 17-24.

Çinar, İbrahim ve Oya Kavlak. 2009. "İzmir İlinde Çalışan Ambulans ve Acil Bakım Teknikerlerinde İş Doyumunun ve Buna Etki Eden Faktörlerin İncelenmesi”. Acil Tip Dergisi 8/3: 33-37.

Dede, Meral ve Sezgi Çınar. 2008. "Dahiliye Yoğun Bakım Hemşirelerinin Karşılaştıkları Güçlükler ve İş Doyumlarının Belirlenmesi”. Maltepe Üniversitesi Hemşirelik Bilim ve Sanatı Dergisi 1/1: 3-14.

Durmuş, Selma ve Osman Günay. 2007. "Hemşirelerde İş Doyumu ve Anksiyete Düzeyini Etkileyen Faktörler”. Erciyes Tip Dergisi 29/2: 139-146.

Ebeling, Jon S. ve Michael King. 1981. "Hierarchical Position in the Work Organization and Job Satisfaction: A Failure to Repliate". Human Relations 34/7: 567-572.

Ergin, Canan. 1997. "Bir İş Doyumu Ölçümü Olarak "İş Betimlemesi Ölçeği”": Uyarlama, Geçerlik ve Güvenirlik Çalışması". Türk Psikoloji Dergisi 12/39: 2536. 
Erol, Almıla, Aybala Sarıçiçek ve Şeref Gülseren. 2007. "Asistan hekimlerde tükenmişlik: İş doyumu ve depresyonla ilişkisi”. Anadolu Psikiyatri Dergisi 8: 241-247.

Gençtürk, Aycan ve Aysel Memiş. 2010. "İlköğretim Okulu Öğretmenlerinin Öz-Yeterlik Algıları ve İş Doyumlarının Demografik Faktörler Açısından İncelenmesi”. Elemantary Education Online 9/3: 1037-1054.

Işıkhan, Vedat. 1996. "Sosyal Hizmet Örgütlerinin İşlevsellik Ölçütü: İş Doyumu”. MPM, Verimlilik Dergisi 1: 117-130.

Kağan, Mücahit. 2005. "Devlet ve Özel İlköğretim İlkokulları ile Rehberlik ve Araştırma Merkezlerinde Çalışan Rehber Öğretmenlerin İş Doyumlarının İncelenmesi - Ankara İli Örneği”. Yüksek Lisans Tezi, Ankara Üniversitesi.

Kavlu, İnci ve Rukiye Pınar. 2009. “Acil Servislerde Çalışan Hemşirelerin Tükenmişlik ve İş Doyumlarının Yaşam Kalitesine Etkisi”. Türkiye Klinikleri Journal of Medical Sciences 29/6: 1543-55.

Kayıkçı, Kemal. 2005. "Milli Eğitim Bakanlığı Müfettişlerinin Denetim Sisteminin Yapısal Sorunlarına İlişkin Algıları ve İş Doyum Düzeyleri”. Kuram ve Uygulamada Ĕ̈itim Yönetimi 11/4: 507-527.

Kelecioğlu, Hülya, Filiz Bilge ve Yasemin Akman. 2006. "Öğretim Elemanları İş Doyumu Ölçeğinin Geliştirilmesi”. Türk Psikoloji Danışma ve Rehberlik Dergisi 3/26: 32-41.

Keser, Aşkın. 2006. “Çağrı Merkezi Çalışanlarında İş Yükü Düzeyi İle İş Doyumu İlişkisinin Araştırılması”. Kocaeli Üniversitesi Sosyal Bilimler Enstitüsü Dergisi 11/1: 100-119.

Kurçer, Mehmet Ali. 2005. "Harran Üniversitesi Tip Fakültesi Hekimlerinin İş Doyumu ve Tükenmişlik Düzeyleri”. Harran Üniversitesi Tıp Fakültesi Dergisi 2/3: 10-15.

Kuzgun, Yıldız, Sevim Aydeniz ve Zeynep Hamamc1. 1999. "Mesleki Doyum Ölçeğinin Geliştirilmesi”. Türk Psikolojik Danışma ve Rehberlik Dergisi 2/11: 14-18.

Pelit, Elbeyi ve Yüksel Öztürk. 2010. “Otel İşletmeleri İşgörenlerinin İş Doyum Düzeyleri: Sayfiye Şehir Otel İşletmeleri İşgörenleri Üzerinde Bir Araştırma”. İsletme Araştırmaları Dergisi 2/1: 43-72.

Sat, Sultan. 2011. "Örgütsel ve Bireysel Özellikler Açısından İş Doyumu İle Tükenmişlik Düzeyi Arasındaki İlişki: Alanya’ da Banka Çalışanları Üzerinde Bir İnceleme”. Yüksek Lisans Tezi, Çukurova Üniversitesi.

Sat, Sultan ve Ünal Ay. 2010. "Banka Çalışanlarının İş Doyumu ve Tükenmişlik Düzeylerinin İncelenmesi”. İktisadi ve İdari Bilimler Fakültesi Dergisi 14/2: 47 66.

Solmuş, Tarık. 2004. İş yaşamında Duygular ve Kişilerarası İlişkiler. İstanbul: Beta Basim.

Tarlan, Deniz ve Özkan Tütüncü. 2001. "Konaklama İşletmelerinde Başarım Değerlendirmesi ve İşdoyumu Analizi”. Dokuz Eylül Üniversitesi Sosyal Bilimler Enstitüsü Dergisi 3/2: 141-163. 
Taşdan, Murat ve Eda Tiryaki. 2008. “Özel ve Devlet İlköğretim Okulu Öğretmenlerinin İş Doyumu Düzeylerinin Karşılaştırılması”. Eğitim ve Bilim 33/147:147.

Toker, Boran. 2007. “Demografik Değişkenlerin İş Tatminine Etkileri: İzmir'deki Beş ve Dört Yıldızlı Otellere Yönelik Bir Uygulama”. Doğuş Üniversitesi Dergisi 8/1: 92-107.

Şahin, Hülya ve Aylin Dursun. 2009. "Okul Öncesi Öğretmenlerinin İş Doyumları: Burdur Örneği”. Mehmet Akif Ersoy Üniversitesi Eğitim Fakültesi Dergisi 9/18: 160-174.

Gülseren, Ünal Keskin. 2005. “Bir Ruh Sağlığı ve Hastalıkları Hastanesinde Çalışan Hekim ve Hemşirelerin Klinik Ortamlarını Değerlendirmeleri ile İş Doyumları Arasındaki İlişkinin İncelenmesi”. Anadolu Psikiyatri Dergisi 6: 213- 220.

Ünal, Süheyla, Rıfat Karlıdağ ve Saim Yoloğlu. 2001. "Hekimlerde Tükenmişlik ve İş Doyumu Düzeylerinin Yaşam Doyumu Düzeyleri ile İlişkisi”. Klinik Psikiyatri 4: 113-118.

Yasan, Aziz, Altan Eşsizoğlu, Murat Yalçın ve Mustafa Özkan. 2008. “Bir Üniversite Hastanesinde Çalısan Araştırma Görevlilerinde İş Memnuniyeti, Anksiyete Düzeyi ve İlişkili Etmenler”. Dicle Tip Dergisi 35/ 4: 228-233.

Yelboğa, Atilla. 2007. "Bireysel Demografik Değişkenlerin İş Doyumu İle İlişskisinin Finans Sektöründe İncelenmesi”. Çağ Üniversitesi Sosyal Bilimler Dergisi 4/2: 1-19.

Yerlisu, Tennur ve Barbaros Çelenk. 2008. "Liglerde Görev Yapan Voleybol Antrenörlerinin İş Doyum Düzeylerinin Değerlendirilmesi”. Spormetre Beden Eğitimi ve Spor Bilimleri Dergisi 6/2: 87-93.

Yıldırım, Fatma. 2007. “İş Doyumu İle Örgütsel Adalet İlişkisi”. Ankara Üniversitesi SBF Dergisi 62/1: 253-278.

Yılmaz, Ali ve Çiğdem Ceylan Boğa. 2011. “İlköğretim Okul Yöneticilerinin Liderlik Davranış Düzeyleri ile Öğretmenlerin İş Doyumu İlişkisi”. Kuram ve Uygulamada Eğitim Yönetimi. 17/2: 277-394. 


\title{
Factors Affecting Job Satisfaction of Factory Workers
}

\section{MEHMET KÖK}

\author{
ARZU ÇAKICI
}

\begin{abstract}
The purpose of this study is to measure work satisfaction of workers employed at waste recycling factories in Kocaeli-Izmit center by Minnesota Satisfaction Scale and to examine the extent to which it is predicted with demographic variables including age, gender, marital status, level of education, total income, rank, working hours, managership, selection of job, suitability for work, commitment to work, night duties, managership and meeting of personal needs. The study was attended by 150 workers chosen with easy access sampling method in Izmit province in 2013, but data collection tools were returned by 67 workers. Democratic information gathering form and Minnesota job satisfaction scale was applied to the participants and frequency distribution and unilateral variance analysis was applied for analysing the data.
\end{abstract}

As a result of the conducted analysis, significant difference was not found $(P>0,05)$ as per the dimensions of age, gender, marital status, education level, total income, rank, working hours and managership of those in the sample but significant difference was found $(P<0,05)$ as per status, job selection, suitability for work, commitment to work, night duties, meeting personal needs. Accordingly, job satisfaction of those employees who choose their job not based on conditions but with their free will, who think that the job is suitable for them, those who think that they are committed o their job and those who have no night duties is found to be higher. In addition, the job satisfaction of personnel whose personal needs such as catering and clothing are met by the workplace is found to be higher compared to the otherwise. As regards statute variable, job satisfaction of workers employed at administrative works $(X=3,14)$ is found to be lower than administrative and technical employees $(X=3,99)$. According to the Dunnett's $C$ test, the job satisfaction of workers $(X=3,39)$ and administrative staff $X=3,14)$ is found to be lower than administrative and technical personnel $(X=3,99)$.

Keywords: Job satisfaction, Workers, Factories. 